\title{
Sistem Pengontrol Temperatur dan Kelembaban Otomatis untuk Ruang Penyimpanan Buah
}

\author{
Zulkifli Amin, Muhamad Adha \\ Jurusan Teknik Mesin, Fakultas Teknik, Universitas Andalas, Limau Manis, Padang 25163, Indonesia
}

INFORMASI ARTIKEL

Sejarah Artikel:

Diterima Redaksi: 04 Agustus 2017

Revisi Akhir: 01 September 2017

Diterbitkan: 31 Oktober 2017

\section{KATA KUNCI}

\section{Buah}

Otomatis

Mikrokontroler

Temperatur

Kelembaban

\section{KORESPONDENSI}

E-mail: zulkifliamin@ft.unand.ac.id

\section{A B S T R A C T}

One of the preservation fresh fruit techniques is by using low temperature storage techniqe. This methode is intended to maintain good quality fresh fruits during the period of storage. Maintaining fresh friuts in the suggested low temperature and humidity lead to decelaration the activities of the causes of the spoilage of fresh fruits. Currently, fresh fruit storage methods is only focus on using low temperature storage methods regardless the prerequisites of the temperature nor humidity suggested best for fresh fruit preservation. Nowaday's fruit storages used for maintaining fresh fruit longer is only operated by keeping the storage temperature constant on certain value during the period of storing and the value of the temperature is set manually. However, in order to optimise the results in fruit preservation, the temperature and humidity are also needed to be varied during priod of storage. This article illustrates the development of a system which can automatically control the temperature and humidity of the storage room in accordance with fruit preservation temperature and humidity suggested. In addition, , the temperature and humidity are also can be varied during priod of storage. This research is started by designing and building the electronic wiring system and controlling system. Next, continuing with programming for a microcontroller kit using Arduino IDE software. The container used for the fruit storage is a modified showcase fridge which is equipped with an ultrasonic humidifier and a DHT11 temperature and humidity sensor. The testing is carried out by observing the ability of the controlling unit apparatus to control the temperature and humidity of the storage container based on program inputed into the controller kit. The storage container is controlled to have temperature of $25^{\circ} \mathrm{C}, 10^{\circ} \mathrm{C}$, and $25^{\circ} \mathrm{C}$ accordingly and the humidity of $85 \%$. Both the temperature and humidity of the storage container are then measured and read manually using temperature and humiditymeter HTC-2. These temperature and humidity measurement data are compared with the temperature and humidity automatically measured by the sensors in the the control unit apparatus. The measurement results show that the values of temperatures and humidity measured by both methods are nearly the same. So, it can be concluded that the controlling unit apparatus is worked properly. It can control the temperature and humidity of the storage container as the program inputed into the controller kit and it can read the temperature and humidity accurately. In addition, the experiment using papaya fruits shows that the papaya fruits can be maintained fresh longer.

\section{PENDAHULUAN}

Negara Indonesia memiliki hasil alam yang melimpah, salah satunya buah-buahan. Komuditas buah-buahan di Indonesia memiliki potensi besar untuk dikembangkan, baik untuk pasar dalam negeri maupun sebagai komuditas ekspor [1]. Namun pada kenyataanya negara Indonesia belum mampu untuk memenuhi kebutuhan ekspor buah-buahan. Hal ini terkait dengan buruknya kualitas dan mutu buah yang ada, sehingga buah belum mampu bersaing dengan komuditas ekspor dari negara lain [2]. Buruknya kualitas dan mutu buah berkaitan dengan 
daya simpan buah yang sangat singkat. Aktivitas metabolisme seperti respirasi, transpirasi dan produksi etilen masih terjadi setelah proses panen pada jenis buah-buahan ini. Sehingga mempercepat proses pematangan, penuaan, pelayuan dan pembusukan. Hal ini menyebabkan daya simpan buah semakin menurun [2].

Ada beberapa cara yang dapat dilakukan untuk menjaga kualitas buah, salah satunya ialah metode penyimpanan pada suhu rendah (sekitar $2,2^{\circ} \mathrm{C}-$ $15,5^{\circ} \mathrm{C}$ ) [3]. Penggunaan temperatur rendah dan kelembaban relatif tinggi, dapat menghambat sumber kerusakan seperti aktifitas fisiologis, aktifitas mikroba, transpirasi dan evaporasi sampai batas waktu tertentu [3]. Hal penting yang harus diperhatikan pada penyimpanan dengan temperatur rendah adalah penggunaan temperatur yang tepat, karena penyimpanan tidak boleh dilakukan pada temperatur terlalu rendah karena dapat menyebabkan terjadinya kerusakan buah akibat temperatur dingin (chilling injury) [4].

Untuk menjaga kualitas buah, diperlukan teknologi yang dapat diterapkan untuk menunjang proses peyimpanan buah. Namun, pada kenyataannya petani tradisional di indonesia masih belum menerapkan teknologi penyimpanan buah paska panen karena kebanyakan petani secara individu tidak mampu membeli teknologi penyimpanan buah [5]. Sehingga petani tradisional cenderung menyimpan buah hasil panen pada temperatur ruangan yang menyebabkan daya simpan menjadi pendek atau menggunakan lemari pendingin (cool case) biasa tanpa mengetahui standar penyimpanan buah yang sesuai. Hal ini menyebabkan kualitas buah seperti rasa dan bentuk menjadi tidak bagus lagi. Setiap buah memiliki standar temperatur dan kelembaban optimum untuk penyimpananya. Selain itu setelah proses panen, sebagian besar buahbuahan juga tidak dapat langsung disimpan pada ruang pendingin bertemperatur rendah, karena setelah dikeluarkan dari ruangan pendingin buah akan mengalami pematangan tidak sempurna [6]. Diperlukan perlakuan khusus penyesuian temperatur dan kelembaban bagi buah sebelum masuk ke proses pendinginan.
Teknologi penyimpanan buah saat ini belum optimal dalam hal pengaturan dan pemantauan kondisi temperatur dan kelembaban ruang penyimpanan yang tepat. Alat yang digunakan untuk memperpanjang umur kesegaran buah sekarang ini hanya ditujukan untuk menjaga temperatur pendinginan tetap pada nilai tertentu selama penyimpanan. Sedangkan untuk mendapatkan hasil yang optimal dalam penyimpanan buah juga diperlukan pengaturan temperatur yang bervariasi terhadap waktu selama waktu penyimpanan. Oleh karena itu, pada penelitian ini dilakukan pengembangan terhadap sebuah sistem yang dapat mengontrol temperatur dan kelembaban ruang penyimpanan secara otomatis berdasarkan standar penyimpanan buah yang ada dan temperatur penyimpanan dapat divariasikan secara otomatis selama penyimpanan.

\section{KAJIAN PUSTAKA}

\subsection{Buah dan Metode Penyimpanan Buah Paska Panen}

Masalah yang membatasi perdagangan buahbuahan dan sayuran adalah daya simpannya yang relatif singkat dan besarnya variasi tingkat kematangan sehingga mutunya tidak seragam. Umumnya, pedagang dan pemasok membeli buahbuahan dari petani saat buah tersebut cukup tua tapi belum matang dengan harapan dapat sampai ke tangan konsumen dalam kondisi segar, kualitas kematangan seragam dan siap dikonsumsi [7].

Setelah dipanen, jaringan pada produk pertanian masih hidup. Hal ini dikenal dengan aktifitas fisiologis seperti respirasi, transpirasi dan produksi etilen. Aktifitas fisiologis pada produk pertanian menyebabkan perubahan yang tidak dapat dihentikan namun dapat diperlambat. Tahap akhir dari perubahan tersebut ialah kalayuan. Respirasi adalah suatu proses metabolisme biologis dengan menggunakan oksigen dalam perombakan senyawa untuk menghasilkan $\mathrm{CO}_{2}$, air dan sejumlah besar elektron-elektron. Pada umumnya produk hasil pertanian setelah dipanen masih melakukan proses respirasi serta metabolisme lain sampai bahan tersebut rusak dan proses kehidupan berhenti [8]. 
Tabel 2.1 Temperatur penyimpanan, kelembaban dan daya simpan buah [11]

\begin{tabular}{|l|c|c|c|}
\hline \multicolumn{1}{|c|}{ Komoditi } & Suhu $\left({ }^{\circ} \mathrm{C}\right)$ & Kelembaban $(\%)$ & Daya simpan (hari) \\
\hline Alpukat & 13 & $85-90$ & 14 \\
\hline Pisang sere & $12-15$ & $85-90$ & 28 \\
\hline Cavendis hijau & $12-14$ & $85-90$ & 28 \\
\hline Cavendish matang & 12 & $85-90$ & 7 \\
\hline Pisang berangan & 15 & $85-90$ & 28 \\
\hline Jeruk manis & $8-10$ & 90 & 14 \\
\hline Pepaya & 10 & $85-90$ & 21 \\
\hline Jambu biji & $8-10$ & $85-90$ & 35 \\
\hline Rambutan & 10 & $90-95$ & 18 \\
\hline
\end{tabular}

Etilen merupakan senyawa organik sederhana yang dapat berperan sebagai hormon pengatur pertumbuhan, perkembangan, dan kelayuan. Keberadaan etilen akan mempercepat proses kelayuan [9]. Transpirasi adalah pengeluaran air dari jaringan produk nabati. Transpirasi yang berlebihan menyebabkan pengurangan berat, kelayuan, nilai tekstur dan nilai gizi [10]. Komuditas pada temperatur yang tidak sesuai akan menyebabkan kerusakan fisiologis berupa: Freezing Injuries, Chilling Injuries, Heat Injuries [10].

Penyimpanan dingin adalah sebagai proses pengawetan bahan dengan cara pendinginan pada suhu di atas temperatur bekunya. Secara umum pendinginan dilakukan pada temperatur $2.2^{\circ} \mathrm{C}$ $15.5^{\circ} \mathrm{C}$ tergantung kepada masing-masing bahan yang disimpannya [2]. Pendinginan menuntut adanya pengontrolan terhadap kondisi lingkungan antara lain temperatur yang rendah, komposisi udara, kelembaban dan sirkulasi udara [3]. Temperatur penyimpanan yang digunakan tidak boleh terlalu rendah karena dapat menyebabkan terjadinya kerusakan buah akibat chilling injury [10]. Temperatur penyimpanan untuk buah yang direkomendasikan untuk penyimpanan dapat dilihat pada Tabel 2.1.

Pepaya merupakan buah kalimetrik yang memiliki daya simpan yang sangat singkat. Dari sebuah penelitian yang pernah dilakukan, untuk menjaga kualitas buah pepaya digunakan metode penyimpanan pada temperatur rendah [12]. Penyimpanan pada temperatur yang rendah akan menurunkan nilai kelembaban ruang penyimpanan, sedangkan kelembaban relatif untuk penyimpanan buah pepaya adalah $85-90 \%$, di bawah rentang tersebut, buah akan mengalami kematangan tidak sempurna sebaliknya di atas rentang tersebut akan memicu tumbuhnya jamur yang mempercepat pembusukan [12].

Untuk mendapatkan kualitas buah pepaya yang baik untuk dikonsumsi, dilakukan beberapa tahapan pengendalian temperatur secara manual. Yang pertama yaitu setelah dipetik buah pepaya harus disimpan pada temperatur ruangan (sekitar $25^{\circ} \mathrm{C}$ ) selama 2 hari untuk menyamakan temperatur ruang dan temperatur buah, hal ini bertujuan untuk pematangan yang merata. Setelah itu dilakukan penyimpanan pada temperature $10^{\circ} \mathrm{C}-15^{\circ} \mathrm{C}$ untuk menghambat laju respirasi buah. Selanjutnya buah disimpan kembali pada temperatur ruangan selama 3 hari.

Penyimpanan pepaya untuk keperluan distribusi jarak jauh disarankan pada temperatur $8^{\circ} \mathrm{C}$ karena pada kondisi ini aktifitas fisiologis buah berhenti total. Dibawah temperatur tersebut, kondisi buah tidak akan baik lagi karena mengalami pecah pada daging buah [12].

\subsection{Sistem Kontrol}

Sistem kontrol adalah proses pengaturan maupun pengendalian terhadap satu atau beberapa besaran (variabel, parameter) sehingga berada pada suatu harga atau dalam suatu range tertentu. Sistem kontrol banyak diterapkan di industri. Adapun contoh parameter yang harus dikontrol atau dikendalikan seperti tekanan, aliran, suhu, 


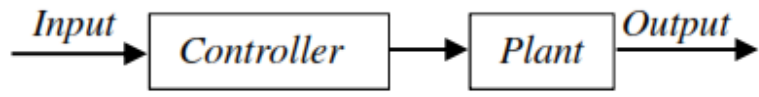

Gambar 2.1 Diagram blok sistem kontrol terbuka [14]

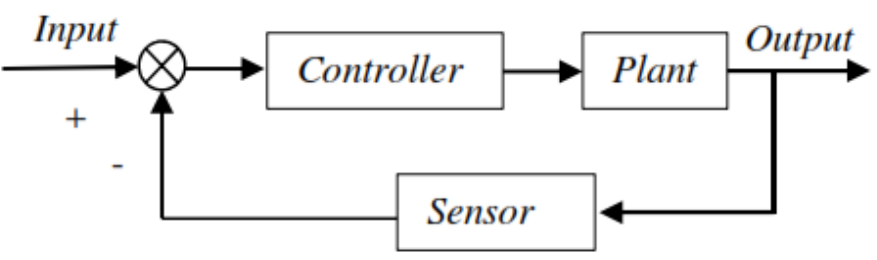

Gambar 2.2 Diagram blok sistem kontrol tertutup [14]

ketinggian, kerapatan, dan lain-lain. Gabungan kerja dari alat-alat kontrol dalam proses produksi dinamakan sistem pengontrolan proses. Semua peralatan yang membentuk sistem pengontrolan disebut proses pengontrolan instrumentasi [13].

Suatu sistem kontrol otomatis dalam suatu proses kerja berfungsi mengendalikan proses tanpa adanya campur tangan manusia. Pada sistem kontrol dikenal sistem kontrol open loop dan close loop. Open Loop (Loop Terbuka) yaitu suatu sistem kontrol yang keluarannya tidak berpengaruh terhadap aksi pengontrolan. Dengan demikian pada sistem kontrol ini, nilai keluaran tidak di umpanbalikkan ke parameter pengendalian seperti pada Gambar 2.1.

Sedangkan Close Loop (Loop Tertutup) yaitu suatu sistem kontrol yang sinyal keluarannya memiliki pengaruh langsung terhadap aksi pengendalian yang dilakukan. Sinyal error yang merupakan selisih dari sinyal masukan dan sinyal umpan balik (feedback), lalu diumpankan pada komponen pengendalian (controller) untuk memperkecil kesalahan sehingga nilai keluaran sistem semakin mendekati harga yang diinginkan. Hal ini dapat dilihat pada Gambar 2.2.

\subsection{Sistem Otomasi Pada Ruang Penyimpanan Buah}

Sistem otomasi pada ruang penyimpanan buah merupakan sebuah sistem yang dapat mengontrol temperatur dan kelembaban yang sesuai dengan kebutuhan buah terhadap waktu penyimpanan yang diinginkan. Untuk itu dibutuhkan beberapa peralatan atau komponen utama untuk pembuatan sistem kontrol ini seperti mesin pendingin, Humidifier, kontroller, Display LCD, motor DC, sensor, relay, dan beberapa komponen elektronika lainnya.

Software pendukung juga dibutuhkan untuk sistim otomasi, seperti Autodesk Inventor 2013,Proteus 8 dan Arduino IDE. Autodesk Inventor 2013 adalah salah satu produk dari Autodesk Corp. yang diperuntukan untuk enginering design and drawing. Autodesk Inventor merupakan produk dari CAD setelah AutoCAD dan Autodesk Mechanical Desktop [15]. Proteus 8 adalah program dari labcenter electronics yang dibuat khusus untuk mensimulasikan rangkaian kontrol elektronika seperti microcontroller, motor stepper, lcd, 7 segment dan lain-lain. Program ini memiliki beberapa keunggulan, diantaranya daftar komponen yang lengkap, analisa rangkaian dan membuat layout PCB [16]. Arduino IDE adalah lingkungan open-source Arduino untuk memudahkan menulis 


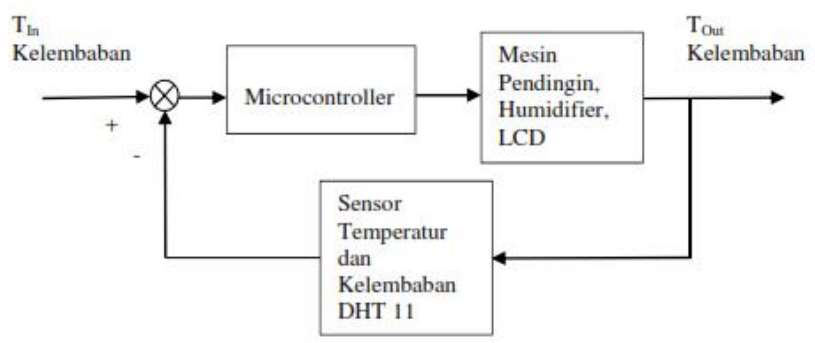

Gambar 3.1 Diagram blok sistem kerja alat

kode dan meng-upload ke board Arduino. Sistem operasi yang dapat digunakan seperti Windows, Mac OS X, dan Linux. Arduino Uno dapat diprogram dengan software Arduino yang dapat didownload di http://arduino.cc/en/Main/Software [17].

\section{METODOLOGI}

Hal yang pertama kali dilakukan dalam penelitian ini adalah identifikasi masalah dan studi literatur. Kemudian berturut - turut dilakukan perancangan sistim kerja alat, perancangan fisik sistem dan perangkat elektronik. Selanjutnya dibuat gambar teknik alat, diikuti dengan penyusunan algoritma dan flowchart pemograman sistem pengontrolan. Setelah itu pengerjaan perangkat elektrik dan perangkat fisik alat, pemrograman sistim serta terakhir dilakukan pengujian sistim dan pengujian alat.

Sistim pengontrolan otomatis pada ruang penyimpanan buah yang akan dirancang mampu melakukan pengambilan keputusan untuk mendinginkan ruang pendingin dan menambah kelembaban udara dalam ruang penyimpanan. Pembacaan temperatur dan kelembaban dilakukan oleh sensor. Sinyal yang diperoleh oleh sensor akan dikirimkan ke kontroler dan diproses oleh kontroler tersebut. Kontroler mengirimkan perintah kepada dua aktuator, yaitu mesin pendingin dan humidifier (untuk menambah kelembaban) melalui relay. Hasil pembacaan ruang penyimpanan akan ditampilkan oleh LCD. Berikut ditampilkan diagram blok sistem pada Gambar 3.1.
Pada sistem pengontrolan otomatis yang dirancang pada ruang penyimpanan buah, digunakan mikrokontrler Arduino Uno sebagai pusat kendali. mikrokontroler ini akan terhubung dengan sensor, $\mathrm{LCD}$, dan rangkian driver relay. Rangkaian driver relay nantinya terhubung juga dengan dua buah peralatan yaitu mesin pendingin dan humidifier untuk menambah kelembaban udara pada ruang penyimpanan. Skema rangkaian elektronik secara keseluruhan dapat dilihat pada Gambar 3.2. Skema rangkaian dibuat dengan menggunakan software Proteus 8.

Rangakaian sensor merupakan rangkaian yang menghubungkan sensor dengan kontroler. Pada rancangan ini digunakan sensor DHT11 yang merupakan sensor yang dapat mendeteksi perubahan temperatur dan kelembaban. Sensor mempunyai empat buah pin yang terdiri dari input tegangan sensor (5 volt DC), ground, $\mathrm{NC}$, dan data. Pin data terhubung langsung pada pin digital 7 pada board Arduino.

Board Arduino yang berfungsi sebagai pusat kendali. Pin VCC 5V berfungsi men-suplai daya ke pin input tegangan untuk sensor DHT11 dan LCD , pin GND berfungsi sebagai ground- nya. Pin input data yang digunakan pada sistem ini hanya pin digital. Pin 2,3,4,5,11, dan 12 terhubung ke LCD, Pin 7 terhunbung ke sensor DHT11, dan pin 8, 9 terhubung ke rangkaian relay yang terhubung dengan mesin pendingin dan ultrasonic humidifier.

LCD atau Liquid Crystal Display berfungsi untuk menampilakan pembacaan data oleh sensor pada ruang penyimpanan buah. Untuk mengaktifkan LCD dibutuhkan tegangan 5V dari pada pin VCC. 


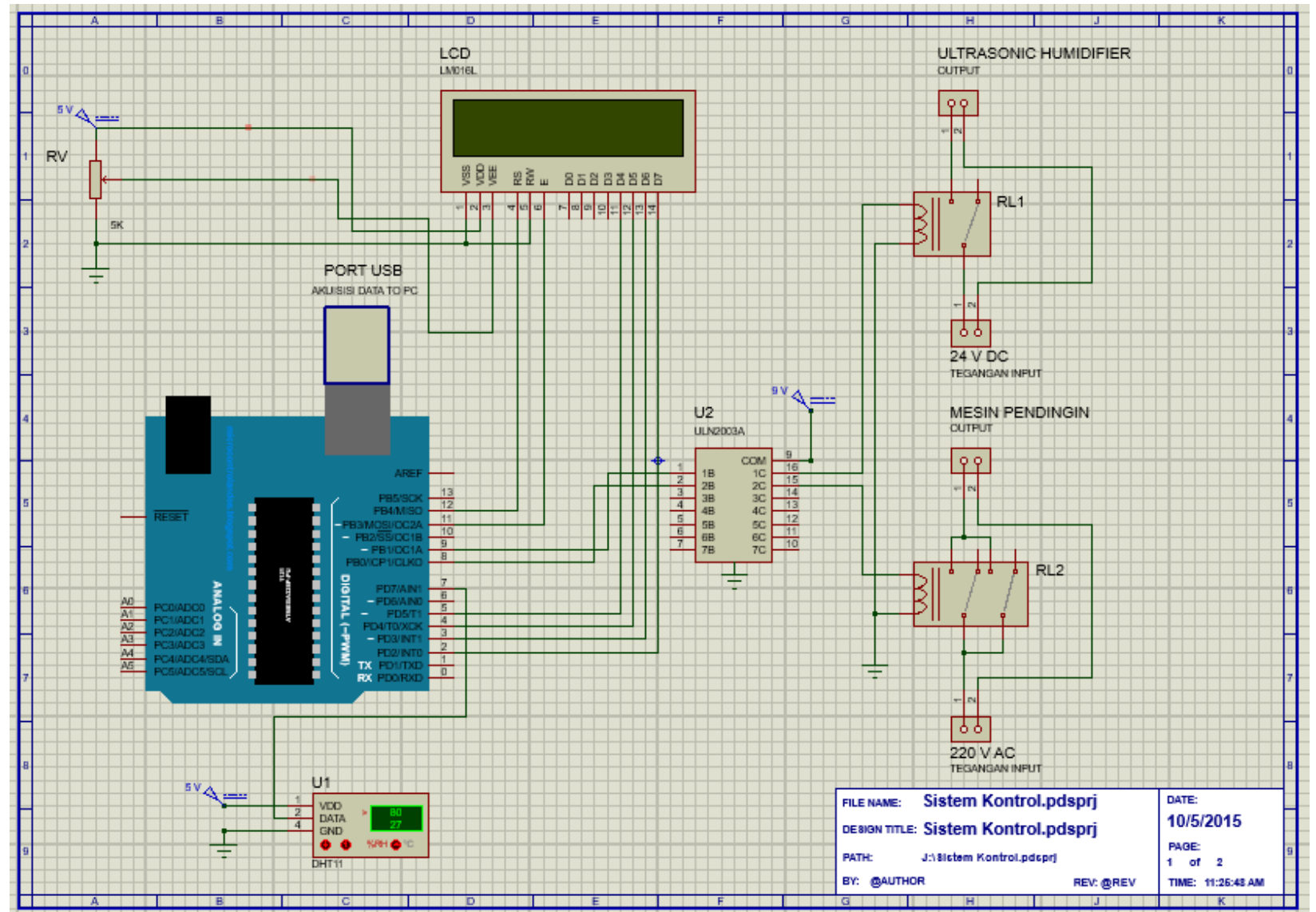

Gambar 3.2 Skema rangkaian elektronik sistem kontrol

Untuk mengatur kecerahan layar pada LCD digunkan potensiometer $5 \mathrm{~K}$ Ohm yang merupakan jenis resistor variabel yang pinnya terhubung dengan VCC, GND dan RW, Vo. Selanjutnya pin Rs, Rw, D4, d5, D6, D7 pada LCD masing - masing terhubung pada pin pin $12,11,5,4,3,2$ pada pin Arduino.

Untuk mengontrol keluaran atau output yang memiliki tegangan yang besar tidak memungkinkan bagi mikrokontroler Arduino. Mikrokontroler Arduino hanya mampu mengeluarkan tegangan output maksimal 5 volt DC, sedangkan pada sistem yang dirancang ini tegangan keluaran yang diharapkan ialah sebesar 24 volt DC untuk menghidupkan ultrasonic humidifier dan 220 volt AC untuk mengaktifkan mesin pendingin. Oleh sebab itu digunakan rangkaian relay yang terhubung dengan IC ULN2003 yang mana dua buah pinnya akan terhubung dengan pin keluaran digital pada mikrokontroler Arduino. Relay yang berfungsi sebagai Switch mampu diaktifkan oleh mikrokontroler Arduino dan menghubungkan keluaran yang besar (AC) tanpa mempengaruhi kerja mikrokontroler Arduino.

Agar rancangan yang akan dibuat berjalan dengan baik, maka diperlukan langkah - langkah kerja yang harus dilakukan oleh sistem pengontrolan otomatis ini. Langkah kerja atau algoritma dan flowchart (pada Gambar 3.3) dari sistem pengontrolan ini dimulai dari menaktifkan Sistem Pengontrolan, kemudian ketika program dijalankan maka sensor membaca perubahan temperatur dan kelembaban pada ruang penyimpanan. Setelah itu, sinyal diolah oleh mikrokontroler sesuai dengan program yang diinputkan. Kemudian, sinyal tersebut dikirim ke driver relay untuk proses pengeksekusian di dalam ruang penyimpanan. Jika temperatur ruang besar dari temperatur referensi, maka mesin pendingin hidup. Jika telah temperatur ruang sama atau kurang dari temperatur referensi maka mesin pendingin 


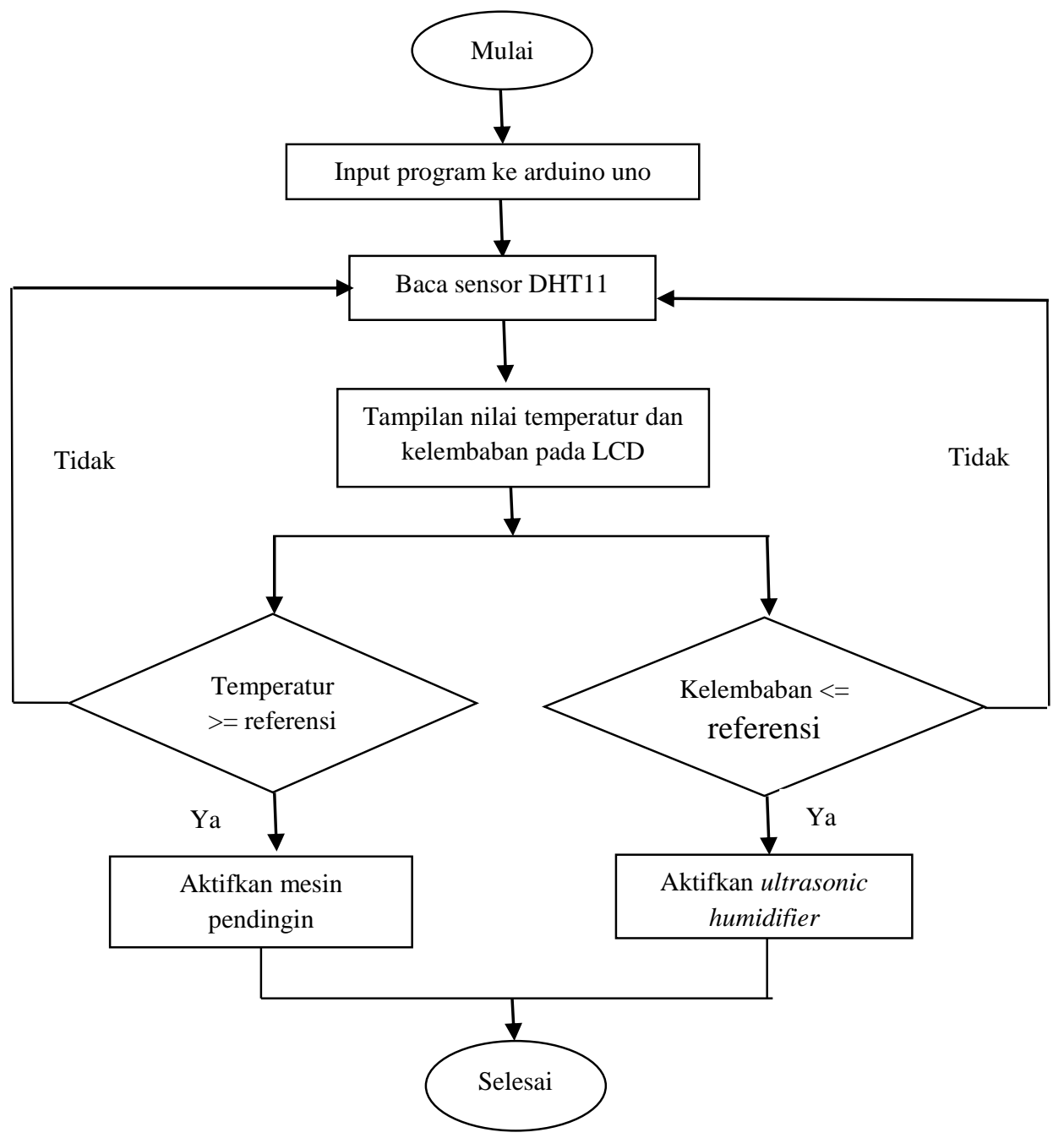

Gambar 3.3 Flowchart pemograman sistem pengontrolan

mati. Begitu juga dengan kelembaban, kelembaban ruang kecil dari kelembaban referensi maka ultrasonic humidifier hidup. Jika kelembaban ruang sama atau lebih dari kelembaban referensi maka ultrasonic humidifier akan mati. Pengulangan proses akan dilakukan untuk nilai referensi yang berbeda.

Pengujian sistem dilakukan dengan cara membandingkan pembacaan sensor pada ruang penyimpanan saat program dijalankan. Perbandingan pembacaan data dilakukan secara manual dengan menggunakan alat ukur Temperatur dan Humidity meter. Terdapat tiga jenis pengujian yang dilakukan, yang pertama yaitu mengamati pengaruh penurunan temperatur ruangan yang dikontrol sampai $8^{\circ} \mathrm{C}$ pada ruang penyimpanan terhadap kelembaban yang tak terkontrol. Yang kedua yaitu pengontrolan temperatur secara kontinu pada temperatur $25^{\circ} \mathrm{C}-15^{\circ} \mathrm{C}-10^{\circ} \mathrm{C}$ dengan rentang waktu yang diasumsikan berdasarkan lama waktu penyimpanan yang sebenarnya. Selain temperatur, kelembaban ruangan juga dikontrol sesuai dengan kelembaban relatif yang disarankan yaitu $85 \%$. Pengujian ketiga dilakukan dengan pemberian objek uji coba berupa buah pepaya sebagai beban pendinginan. Pengujian berlangsung selama 21 hari dengan pengontrolan temperatur dan kelembaban seperti hampir sama dengan pengujian dua, namun dengan input nilai temperatur yang sedikit berbeda yaitu $25^{\circ} \mathrm{C}-10^{\circ} \mathrm{C}-25^{\circ} \mathrm{C}$. Buah pepaya yang diletakan didalam lemari pendingin dibandingkan laju kematanganya dengan buah pepaya yang diletakan pada ruangan kamar. 


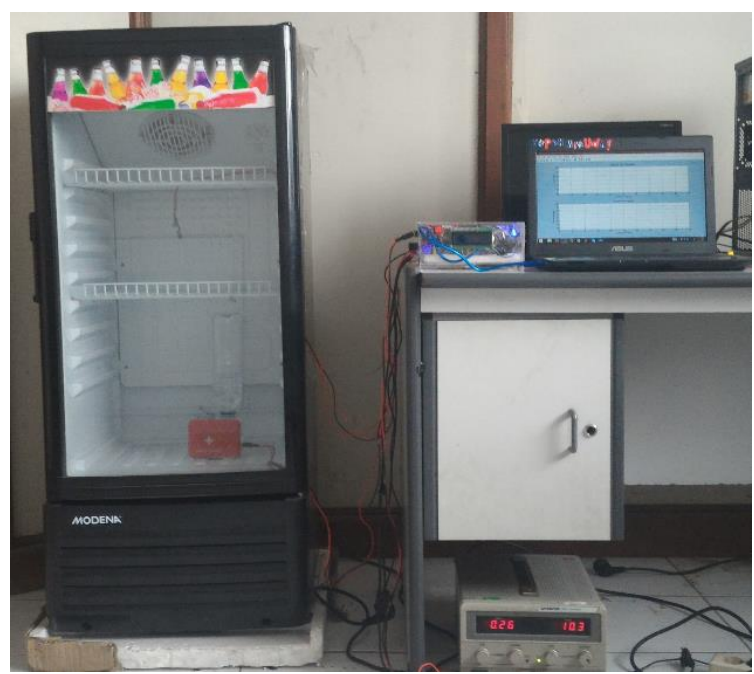

Gambar 4.1 Hasil rancangan sistem pengontrol temperatur dan kelembaban otomatis pada ruang penyimpanan buah

Pengujian alat mengacu pada penelitian yang pernah dilakukan sebelumnya. Dimana pada penelitian sebelumnya pengesetan nilai temperatur dan kelembaban dilakukan secara manual. Sedangkan pada penelitian ini dilakukan pengesetan nilai temperatur dan kelembaban secara otomatis dengan membuat sistem pengontrol yang dapat merekayasa kondisi ruang penyimpanan buah berdasarkan inputan nilai yang disesuaikan.

\section{HASIL DAN PEMBAHASAN}

\subsection{Hasil Rancangan Sistem Pengontrol Temperatur dan Kelembaban Otomatis}

Pengerjaan alat dilakukan setelah semua desain perancangan selesai dikerjakan. Bentuk alat yang telah dibuat dapat dilihat pada Gambar 4.1.

Secara keseluruhan sistem pengontrolan otomatis pada ruang penyimpanan buah terdiri atas dua bagian yaitu pertama, kotak kontrol yang berisikan rankaian elektronika yang berfungsi sebagai pengontrol dan yang kedua, mesin pendingin. Pada Gambar 4.2 dapat dilihat bentuk dari kotak kontrol untuk sistem pengontrol ruang penyimpanan buah. Kotak kontrol berfungsi sebagai pusat kendali untuk memproses pembacaan sensor. Kotak kontrol dapat dihubungkan ke PC dan ruang penyimpanan.

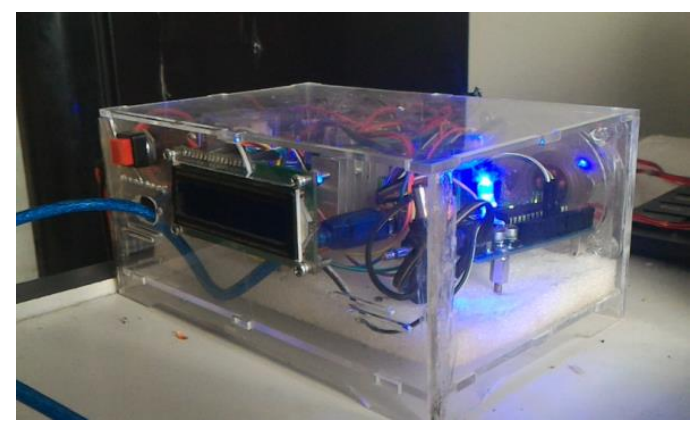

Gambar 4.2 Kotak kontrol

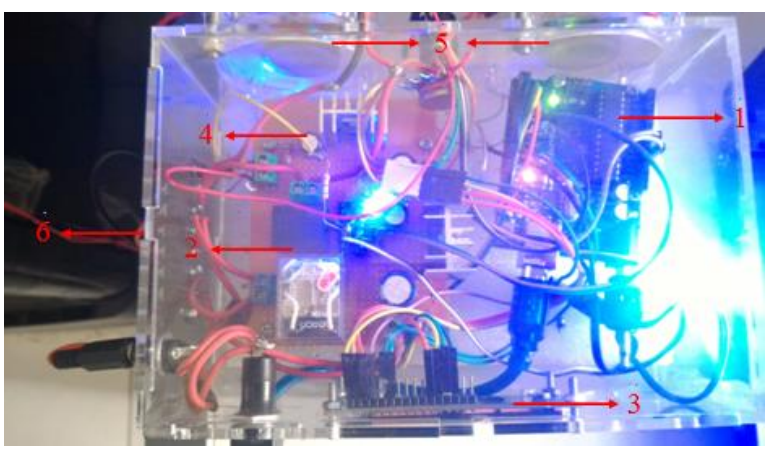

Gambar 4.3 Rangkaian elektronika didalam kotak kontrol

Pada kotak kontrol ini, terdapat beberapa perangkat elektronik yang mendukung kerja sistem alat secara keseluruhan. Pada Gambar 4.3 diperlihatkan bagian - bagian komponen elektronik pendukung sistem kerja alat. Gambar yang diberi label nomor 1 merupakan pusat kendali dari sistem, yaitu mikrokontroler Arduino Uno. Arduino Uno terhubung ke sensor DHT11, rangkaian driver relay, LCD, dan PC. Gambar dengan label nomor 2 merupakan rangkaian driver relay. Dengan menggunakan IC ULN2003A terdapat dua buah relay yang terhubung ke dua buah output, yitu ultrasonic humidifier dan mesin pendingin. Pada gambar dengan label nomor 3 merupakan LCD yang berfungsi sebagai display untuk menampilkan data pembacaan ruang. Pada gambar dengan label nomor 4 merupakan rangakaian catu daya yang merupakan suplay tegangan untuk kebutuhan rangkaian. Gambar dengan label nomor 5 merupakan motor dc fan yang berfungsi sebagai pendingin kotak kontrol. Label nomor 6 merupakan terminal untuk sistem kelistrikan alat. 


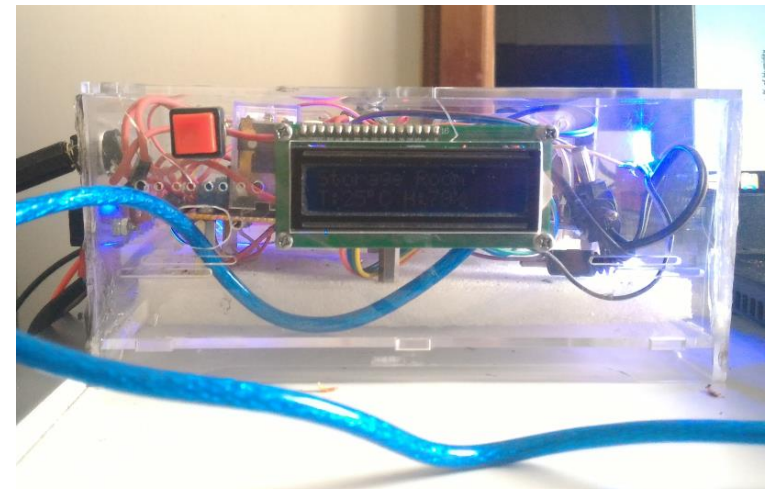

Gambar 4.4 Tampilan pembacaan ruang oleh LCD

Saat pengoperasian alat, kotak kontrol mampu menampilkan pembacaan ruang penyimpanan buah pada LCD seperti pada Gambar 4.4.

Pada mesin pendingin yang digunakan sebagai ruang uji coba alat, diletakan sensor DHT11 yang berfungsi membaca perubahan keadaan ruang. Selain itu pada bagian bawah ruang penyimpanan diletakan ultrasonic humidifier berfungsi untuk menambah kelembaban pada ruang penyimpanan.

\subsection{Pengujian pada Sistem Pengontrol Temperatur dan Kelembaban Otomatis untuk Ruang Penyimpanan Buah}

Untuk melihat kemampuan alat yang telah dibuat, maka dilakukan beberapa jenis pengujian. Pertama pengujian pembacaan data pengaruh penurunan temperatur ruang penyimpanan terhadap waktu. Kedua pengujian pembacaan data temperatur dan kelembaban ruang penyimpanan terkontrol. Ketiga, pengujian pembacaan data temperatur dan kelembaban ruang penyimpanan terkontrol dengan pemberian beban pendinginan (buah pepaya).

Pada pengujian pertama temperatur ruang penyimpanan diturunkan secara otomatis sampai $8^{\circ} \mathrm{C}$ oleh kontroler dan kelembaban ruang dibiarkan tanpa pengontrolan. Untuk menurunkan temperatur ruang penyimpanan hingga mencapai temperatur $8^{\circ} \mathrm{C}$ dibutuhkan waktu selama 42 menit dari awal pengaktifan program. Program yang diinputkan memerintahkan apabila nilai temperatur telah mencapai $8^{\circ} \mathrm{C}$ maka secara otomatis mesin akan mati. Namun mesin pendingin berhenti disaat display menunjukan nilai $7^{\circ} \mathrm{C}$. Hal ini terjadi dimungkinkan karena pengambangan nilai yang dibaca sensor sehingga display menunjukan nilai yang berbeda dari nilai yang diinputkan. Namun jika nilai pembacaan data oleh pengontrol dibandingkan dengan pembacaan nilai alat ukur seperti pada Gambar 4.5, dapat dilihat bahwa grafik yang disajikan menunjukan nilai pembacaan data temperatur oleh pengontrol tidak jauh berbeda dengan nilai pembacaan data oleh alat ukur.

Pada awal sistem dioperasikan nilai kelembaban ditunjukan $70 \%$ pada display namun setelah sistem berhenti beroperasi nilai kelembaban menjadi $20 \%$. Pada pengujian yang telah dilakukan tampak bahwa nilai kelembaban relatif yang ditampilkan mengalami penurunan seiring turunnya temperatur ruang pendinginan. Untuk menganalisa fenomena yang terjadi pada proses pendinginan ini, diperlukan kajian dan pembuktian dengan menggunakan diagram psikometrik. Psikometrik merupakan ilmu yang mempelajari sifat - sifat termodinamika dari udara.

Pada diagram psikometrik tampak bahwa penurunan temperatur yang terjadi menunjukan nilai kelembaban menjadi bertambah. Pada temperatur $25^{\circ} \mathrm{C}$ nilai $\mathrm{Rh}$ ialah $50 \%$, setelah diturunkan menjadi $20^{\circ} \mathrm{C}$ nilai $\mathrm{Rh}$ menjadi $70 \%$. Hal ini berbeda dengan hasil yang didapati dari pembacaan sensor dan alat ukur seperti pada Gambar 4.6. Fenomena ini terjadi karena nilai pembacaan $\mathrm{Rh}$ pada sensor bukanlah nilai kelembaban relatif pada saat temperatur yang ditunjukan. Karena untuk mendapatkan nilai $\mathrm{Rh}$ yang sesuai masih harus melewati tahapan kondensasi dan pemisahan air dari udara saat udara tak sangggup menampung uap air lagi.

Pada pengujian kedua diberikan perintah pemograman pada kotak kontrol untuk menurunkan temperatur ruang menjadi $25^{\circ} \mathrm{C}, 15^{\circ} \mathrm{C}$, dan $10^{\circ} \mathrm{C}$, secara otomatis dan bertahap dengan waktu jeda masing- masing 1, 3, dan 2 menit oleh kotak kontrol. Untuk mencapai temperatur $10^{\circ} \mathrm{C}$ pengontrol membutuhkan waktu selama 1 jam 22 menit. Data yang didapat oleh pengontrol dibandingakan dengan pengukuran secara manual. Perbandingan data yang didapat cukup memiliki 


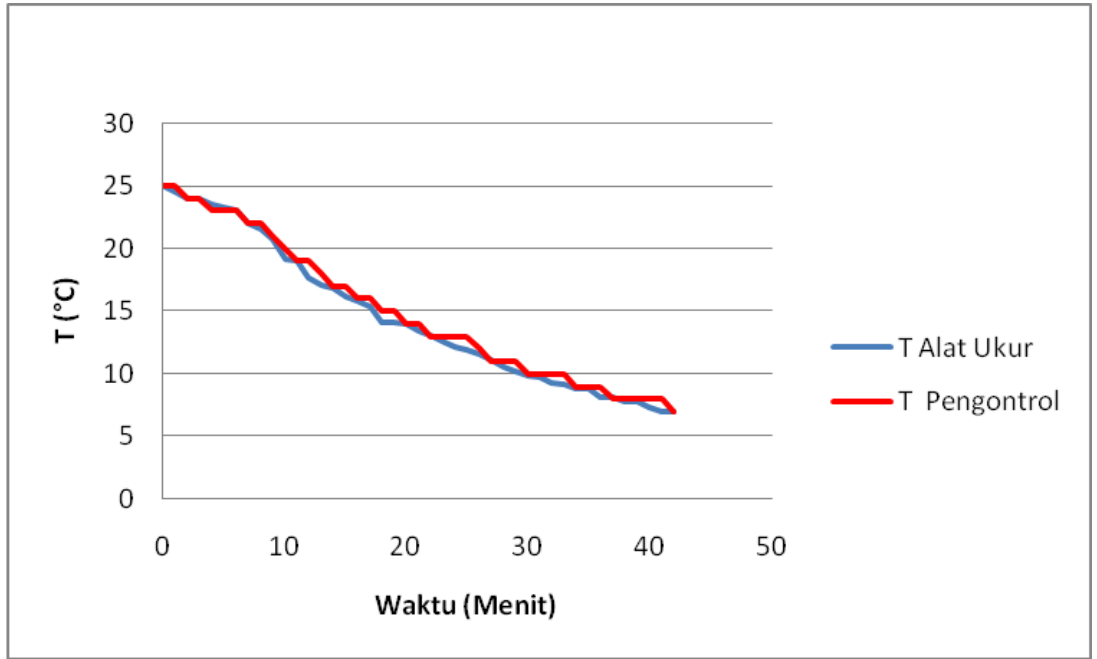

Gambar 4.5 Grafik perbandingan penurunan temperatur terhadap waktu dari hasil pembacaan ruang secara manual dan otomatis

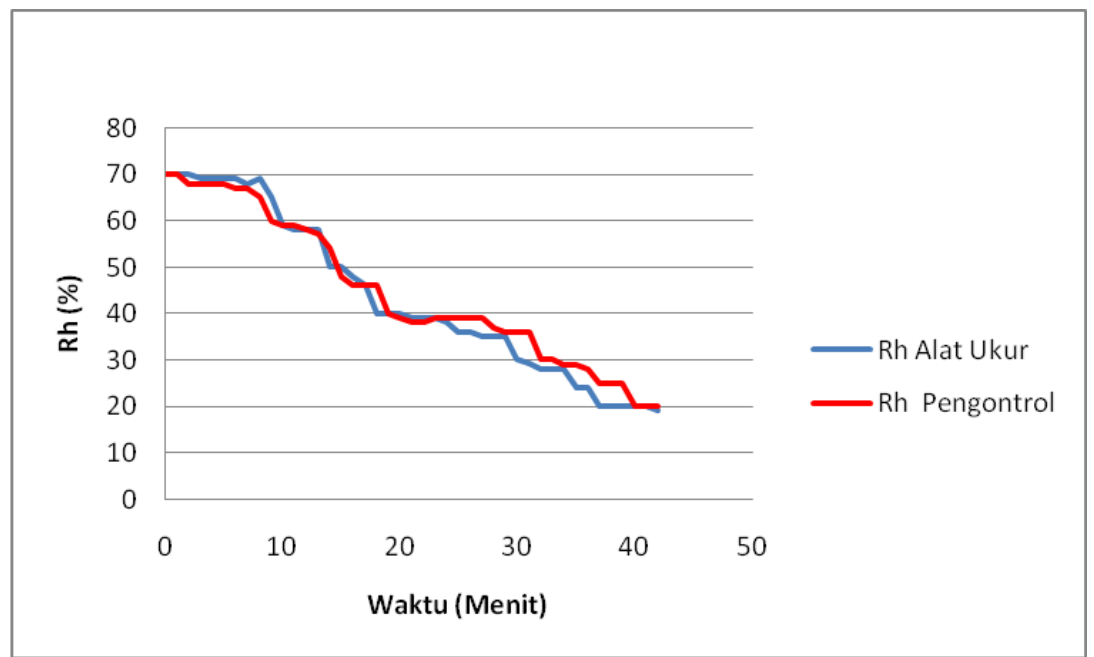

Gambar 4.6 Grafik perbandingan penurunan kelembaban terhadap waktu dari hasil pembacaan ruang secara manual dan otomatis

rentang selisih nilai perbandingan yang lumayan beragam (Gambar 4.7). Hal ini terjadi karena perbedaan respon pembacaan data baik oleh alat ukur maupun oleh sensor.

Nilai kelembaban juga dikontrol pada pengujian kedua ini, yaitu pada kelembaban $85 \%$. Untuk membuat kelembaban ruang sesuai dengan nilai yang diinputkan, ultrasonic humidifier melakukan pengaktifan sebanyak empat kali. Berbeda dengan hasil perbandingan data kelembaban ruang pada pengujian pertama, nilai pembacaan kelembaban oleh sensor dan pembacaan oleh alat ukur memiliki rentang nilai yang cukup jauh seperti yang ditunjukan Gambar 4.8. Hal ini dikarenakan pembacaan nilai kelembaban oleh alat ukur cenderung berubah - ubah secara cepat, sedangkan pembacaan nilai kelembaban pada kotak kontrol cenderung sedikit lambat. Oleh sebab itu terjadi sedikit perbedaan pembacaan nilai data. Selain itu perubahan nilai kelembaban pada ruangan sangat dipengaruhi oleh penurunan temperatur setiap waktunya. 


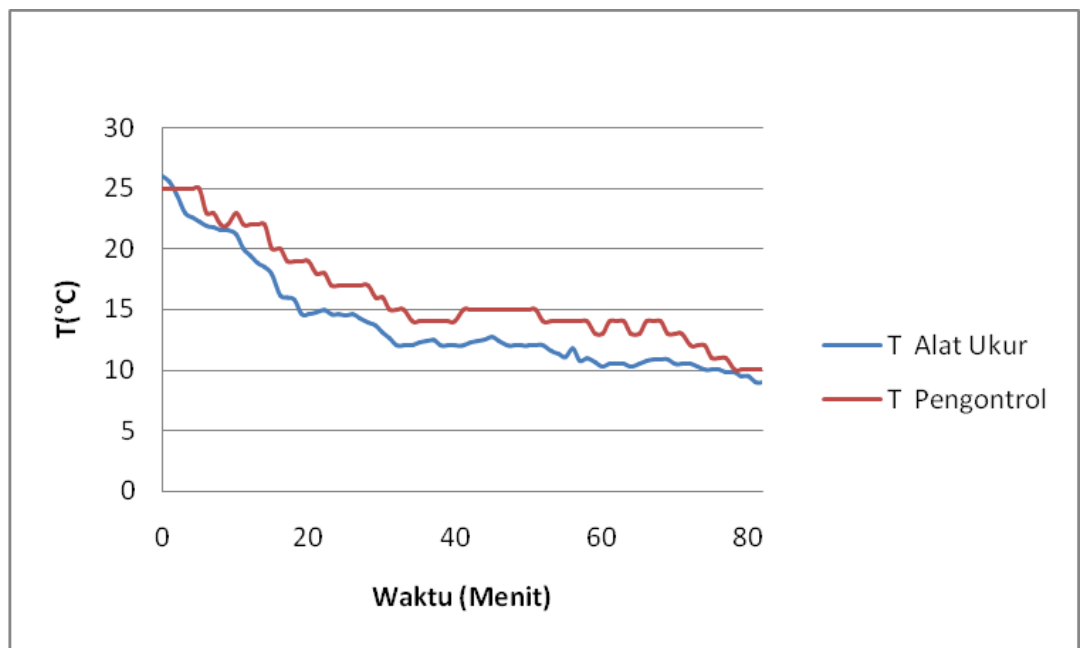

Gambar 4.7 Grafik perbandingan temperatur terkontrol terhadap waktu dari hasil pembacaan ruang secara manual dan otomatis

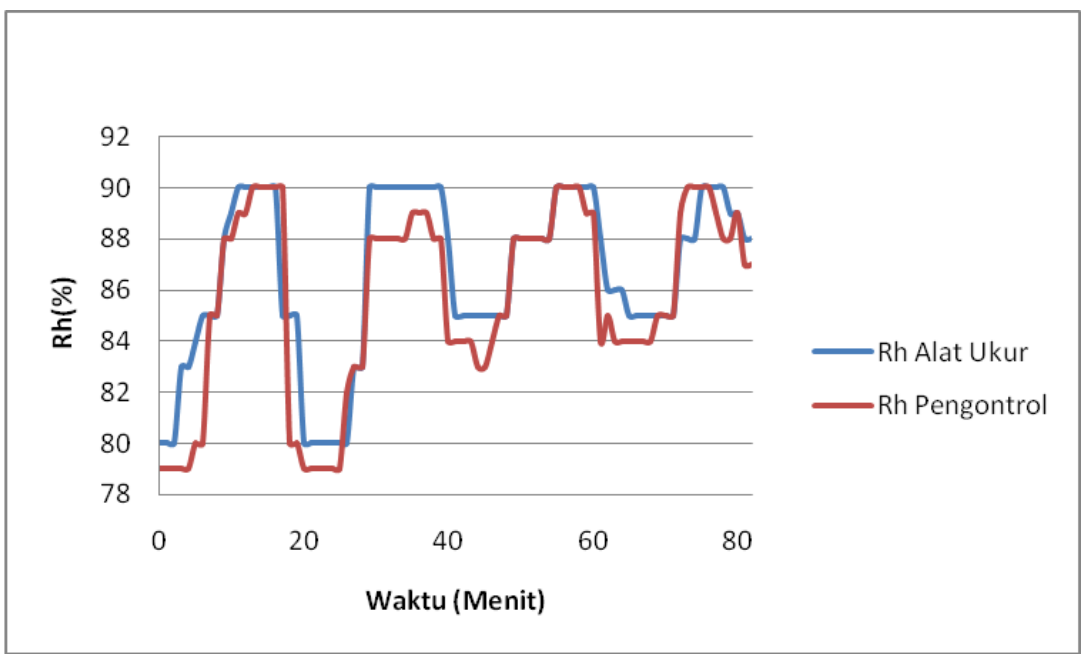

Gambar 4.8 Grafik perbandingan Kelembaban terkontrol terhadap waktu dari hasil pembacaan ruang secara manual dan otomatis

Sedangkan pada pengujian ketiga perintah program yang diinputkan memiliki nilai kelembaban yang sama dengan perintah program pada pengujian kedua namun pada nilai temperatur sedikit berbeda. Nilai yang diinputkan yaitu $25^{\circ} \mathrm{C}, 10^{\circ} \mathrm{C}$, dan $25^{\circ} \mathrm{C}$, dimana pengujian dilakukan selama 26 hari dengan memberikan beban pendinginan berupa buah pepaya didalam ruang pendingin. Nilai yang dibaca oleh pengontrol, baik itu nilai temperatur dan nilai kelembaban relatif memiliki rentang pembacaan yang tidak terlalu jauh dengan pembandingnya (alat ukur). Dengan kata lain, alat sudah dapat dikatakan mampu bekerja cukup baik, karena nilai pembacaanya tidak jauh berbeda jika dibandingkan dengan alat ukur yang telah terkalibrasi. Selain perbandingan dengan alat ukur yang terkalibrasi, pada Gambar 4.9 dan 4.10 terlihat bahwa nilai pembacaan temperatur dan kelembaban relatif ruangan (kamar). Nilai tersebut hanya sebagai pendukung dari pengamatan objek uji sampel buah yang diletakan pada ruangan kamar biasa sebagai pembanding sampel yang disimpan didalam ruang pendingin. 


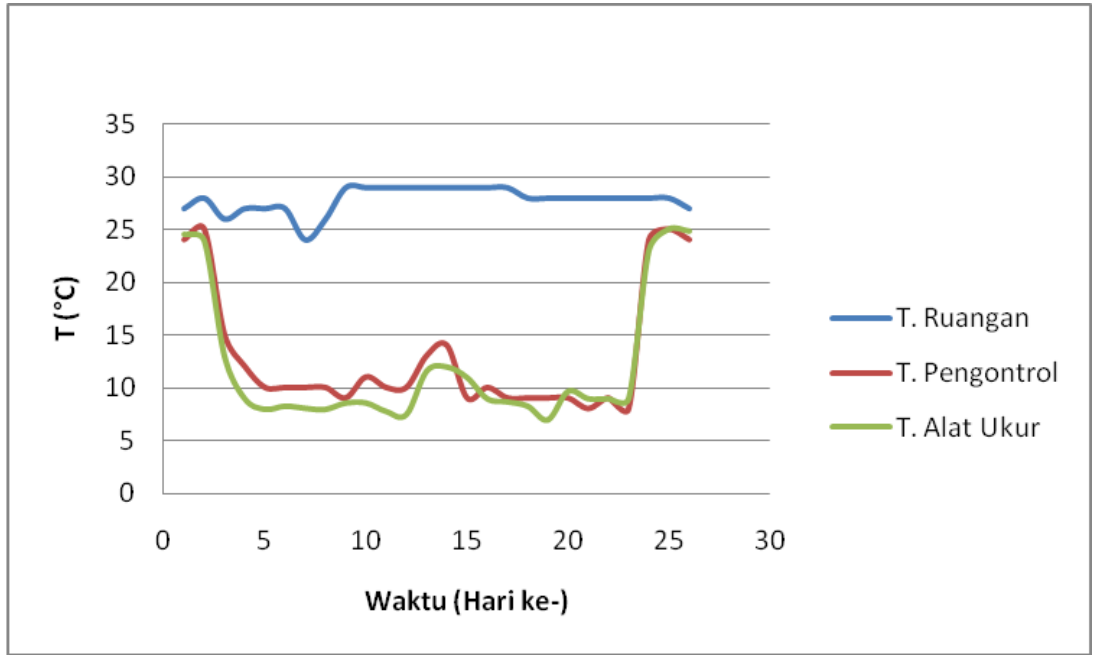

Gambar 4.9 Grafik perbandingan Temperatur terkontrol terhadap waktu dari hasil pembacaan ruang secara manual dan otomatis dengan pemberian beban pendinginan

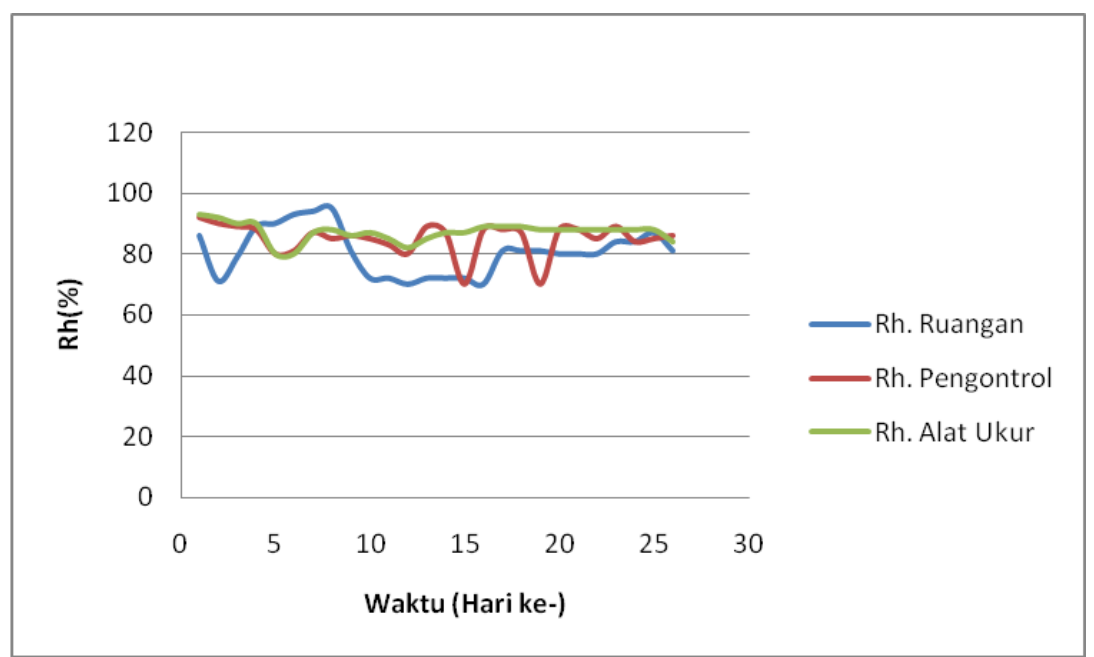

Gambar 4.10 Grafik perbandingan Kelembaban terkontrol terhadap waktu dari hasil pembacaan ruang secara manual dan otomatis dengan pemberian beban pendinginan
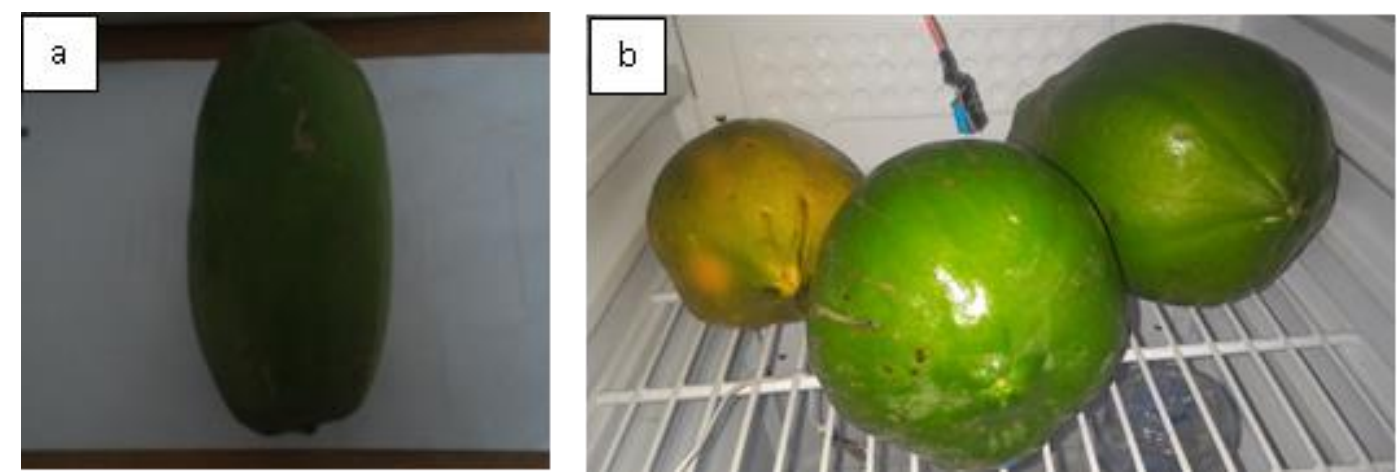

Gambar 4.11 Buah pepaya sebagai sampel uji (a) pepaya yang diletakan di luar mesin pendingin (b) pepaya yang diletakan didalam mesin pendingin 
Jika dibandingkan dengan penelitian tentang buah pepaya sebelumnya, hasil penundaan pematangan buah yang dilakukan dengan mengatur kondisi temperatur dan kelembaban ruang secara manual memiliki hasil yang hampir sama dengan hasil yang diujikan dengan menggunakan sistem pengontrol temperatur dan kelembaban secara otomatis. Buah pepaya sama-sama bisa diperlambat proses pematangannya.

Selain menganalisa kemampuan alat untuk mengontrol temperatur dan kelembaban, juga dilakukan analisa terhadap kendala yang terjadi saat pengoperasian alat. Adapun kendala yang terjadi saat pengoperasian alat ialah terjadinya error akibat sistem kelistrikan alat yang masih kurang stabil, sehingga kotak kontrol harus di reset ulang.

\section{KESIMPULAN}

Dari penelitian ini, kesimpulan yang dapat diperoleh adalah sebagai berikut: (1) Pada penelitian ini telah berhasil dikembangkan sistem pengontrolan untuk ruang penyimpanan buah dengan kondisi temperatur dan kelembaban dapat direkayasa secara otomatis berdasarkan lama waktu penyimpanan buah sebenarnya; (2) Nilai temperatur pada ruang penyimpanan mampu dikontrol secara otomatis oleh alat yang dibuat berdasarkan lama waktu penyimpanan yaitu pada temperatur $25^{\circ} \mathrm{C}$, lalu diturunkan ke temperatur $10^{\circ} \mathrm{C}$, kemudian dinaikan kembali ke temperatur $25^{\circ} \mathrm{C}$ sesuai dengan kebutuhan buah pepaya. Sedangkan kelembaban relatif mampu dipertahankan pada nilai $85 \%$ dengan cara pengaktifan ultrasonic humidifier; (3) Pembacaan nilai temperatur dan kelembaban yang dilakukan pengontrol hampir mendekati dengan nilai pembacaan alat ukur yang ada. Hanya memiliki beda pembacaan 1 atau 2 angka, sehingga alat yang dibuat sudah bisa dikatakan cukup akurat; (4) Penyimpanan buah pepaya pada mesin pendingin yang dikontrol dapat menunda laju kematangan buah selama 21 hari, sedangkan buah pepaya yang disimpan di ruangan mengalami pematangan setelah 5 hari kemudian terjadi pembusukan pada buah tersebut.

\section{UCAPAN TERIMA KASIH}

Penelitian ini telah didanai oleh Skim Penelitian Dosen Fakultas Teknik Dana PNBP 2016, dengan nomor kontrak 026/UN.16.09.D/PL/2016 tanggal 29 Agustus 2016. Dalam hal ini penulis mengucapkan terima kasih kepada pimpinan Fakultas Teknik Universitas Andalas.

\section{DAFTAR PUSTAKA}

[1] Budi Daya Pepaya California, 2011. Dilihat 5 maret 2015. http://epetani.pertanian.go.id/

[2] E. N. Silalahi, Pengaruh Suhu dan Lama Penyimpanan Terhadap Mutu Pepaya (Carica Papaya L) IPB 1 Setelah Pemeraman. Hal 1-2, 2007.

[3] E. R. B. Pantastico, A.K. Matto, T. Murata dan K. Ogata. Kerusakan-Kerusakan Karena Pendinginan. Dalam: "Fisilogi Pascapanen Penanganan dan Pemanfaatan Buah-buahan dan Sayur-sayuran Tropika dan Subtropika," E. R. B. Pantastico, ed. Gadjah Mada University, Yogyakarta, 1986.

[4] T. R. Muchtadi, Sugiyono, Ilmu Pengetahuan Bahan Pangan. IPB, Bogor, 1989.

[5] I Made S. Utama, Teknologi Pasca Panen Hortikultura: Permasalahan Dan Usaha Perbaikan.

[6] S. Koswara, Pengolahan Pangan dengan Suhu Rendah. ebookpangan.com. Hal. 6, 2009.

[7] A. R. Angkat, Dilihat 30 April 2015. Analisis Teknologi Penyimpanan dalam Penanganan Pasca Panen Buah-buahan. http://www.bppjambi.info/?v=publikasi\&page $\equiv \underline{3}$

[8] R Syarief, dan A. Irawati. Pengetahuan Bahan untuk Industri Pertanian. Mediyatama Sarana Perkasa. Jakarta, 1988.

[9] Pengawetan buah segar. Dilihat Kamis 30 April 2015. www.warintek.ristek.go.id/pangan.../Pengawe tan\%20buah\%20segar.pdf

[10] E. R. B. Pantastico, Fisiologi Pasca Panen, Penanganan dan Pemanfaatan Buah buahan 
dan Sayur-sayuran Tropika dan Subtropika. Penerjemah: Kamariyani dan Tjitrosoepomo. Gadjah Mada University Press, Yogyakarta, 1989.

[11] F. G. Winarno dan M. Aman. Fisiologi Lepas Panen. Sastra Hudaya. Jakarta, 1981.

[12] E. N. Silalahi, Pengaruh Suhu dan Lama Penyimpanan Terhadap Mutu Pepaya (Carica Papaya L) IPB 1 Setelah Pemeraman. Institut Pertanian Bogor, Bogor, 2007.

[13] Syaifullah Ahmad. 2013. Pembuatan Alat Sistem Pengontrol Temperatur dan Kelembaban pada Ruang Penyimpanan Buah. Universitas Andalas. Padang

[14] NN. Sistem Kontrol. Dilihat Selasa, 2 Juli 2013.

http://repository.usu.ac.id/bitstream/12345678 9/18172/3/Chapter\%20II.pdf

[15] Autodesk Inventor 2013. Dilihat Senin 5 Oktober 2015.2 http://phodesign.blogspot.co.id/2012/06/pengertianautodesk-inventor.html

[16] ISIS PROTEUS, pengalaman dan pengamalan. Dilihat Kamis 14 Mei 2015. https://digihadiy.wordpress.com/2010/11/02/i sis-proteus-pengalaman-dan-pengamalan/

[17] Tutorial Singkat Bahasa Pemrograman Arduino. Dilihat Kamis 14 Mei 2015. http://blog.famosastudio.com/2011/06/tutorial /tutorial-singkat-bahasa-pemrogramanarduino/82 